\title{
DOLINE FILLS - CASE STUDY OF THE FAVERGHERA PLATEAU (VENETIAN PRE-ALPS, ITALY)
}

\section{ZAPOLNITVE VRTAČ - PRIMER S PLANOTE FAVERGHERA (BENEČIJSKE PREDALPE, ITALIJA)}

\author{
Ugo SAURO ${ }^{1}$, Francesco FERRARESE ${ }^{1}$, Roberto FRANCESE ${ }^{4}$, Antonella MIOLA ${ }^{3}$, Paolo MOZZI ${ }^{1}$, \\ Gualtiero Quario RONDO ${ }^{2}$, Luca TROMBINO ${ }^{2}$ \& Gianna VALENTINI ${ }^{3}$
}

\begin{abstract}
UDC 911.2:551.442(450)

Ugo Sauro, Francesco Ferrarese, Roberto Francese, Antonella Miola, Paolo Mozzi, Gualtiero Quario Rondo, Luca Trombino, Gianna Valentini: Doline fills - case study of the Faverghera plateau (Venetian Pre-Alps, Italy)

The sedimentary fills of two dolines in the Faverghera plateau in the Venetian Pre-Alps, south of Belluno, have been investigated. This small plateau is a sub-horizontal surface about $0.5 \mathrm{~km}^{2}$ wide, located on the northeastern slope of Mt. Faverghera (1640 m a.s.l.) hosting nearly 40 karst dolines partially filled by periglacial slope deposits. Topographic survey, electric resistivity tomography (ERT), soil and pollen analyses have been carried on. The structure of the dolines and the characters of the filling deposits indicate that the evolution of these forms has been controlled by the alternation of different climatic and environmental conditions during the Pleistocene. The results indicate that the dolines are "filters" for the sediments, more than good traps, archiving only some of the climatic and environmental changes.

Keywords: dolines morphometry, dolines fillings, paleosols, pollen analysis, Venetian Pre-Alps.
\end{abstract}

Izvleček

UDK 911.2:551.442(450)

Ugo Sauro, Francesco Ferrarese, Roberto Francese, Antonella Miola, Paolo Mozzi, Gualtiero Quario Rondo, Luca Trombino, Gianna Valentini: Zapolnitve vrtač - primer s planote Faverghera (Benečijske predalpe, Italija)

Raziskana je bila zapolnitev dveh vrtač na planoti Faverghera v Benečijskih predalpah južno od Belluna. Na tej majhni planoti obsega okoli $0.5 \mathrm{~km}^{2}$, ki leži v severovzhodnem pobočju gore Faverghera (1640 m n.m.), je blizu 40 vrtač, deloma zapolnjenih s periglacijalnimi pobočnimi odkladninami. Opravljeni sta bila topografski pregled in tomografija električne upornosti (ERT) ter narejene analize prsti in peloda. Struktura vrtač in značilnosti njihove zapolnitve kažejo, da so razvoj teh oblik narekovale klimatske in okoljske spremembe $\mathrm{v}$ pleistocenu. Izsledki kažejo, da so vrtače »sita« za sedimente, več kot dobre pasti v katerih se zato ohranjajo sledi le nekaterih klimatskih in okoljskih sprememb.

Ključne besede: morfometrija vrtač, zapolnitve vrtač, paleoprst, pelodne analize, Benečijske predalpe.

\section{INTRODUCTION}

Dolines are effective sedimentary traps and in most cases the sediment content masks the rock form, creating a so-called surface landform, perceptible as an expression of the surface relief. So doline morphology represents "karst morpho-structures" that are not only a result of karst dissolution, but also derive from other processes: pedogenetic processes, weathering degradation, col- lapse, alluvial and aeolian processes and finally periglacial environment processes (Sauro 2003, 2004). In the study of dolines it is therefore essential to extend beyond a simple analysis of the shape, but make an attempt to interpret the structure and therefore understand both the interrelationships between the bedrock, fill and floor (i.e., soils, etc.), and the structuring and character of the

1 Dipartimento di Geografia dell'Università di Padova, via del Santo 26, 35123 Padova, Italy, ugo.sauro@unipd.it

${ }^{2}$ Dipartimento Scienze Terra dell'Università di Milano, via Mangiagalli, 34, 20133 Milano, Italy

${ }^{3}$ Dipartimento di Biologia dell'Università di Padova, via U. Bassi 58B, 35121 Padova, Italy

${ }^{4}$ Instituto Nazionale di Oceanografia e di Geophisica Sperimentale -OGS, Borgo Grotta Gigante 42/C, 34010 Sgonico, Italy

Received/Prejeto: 29.10.2008 


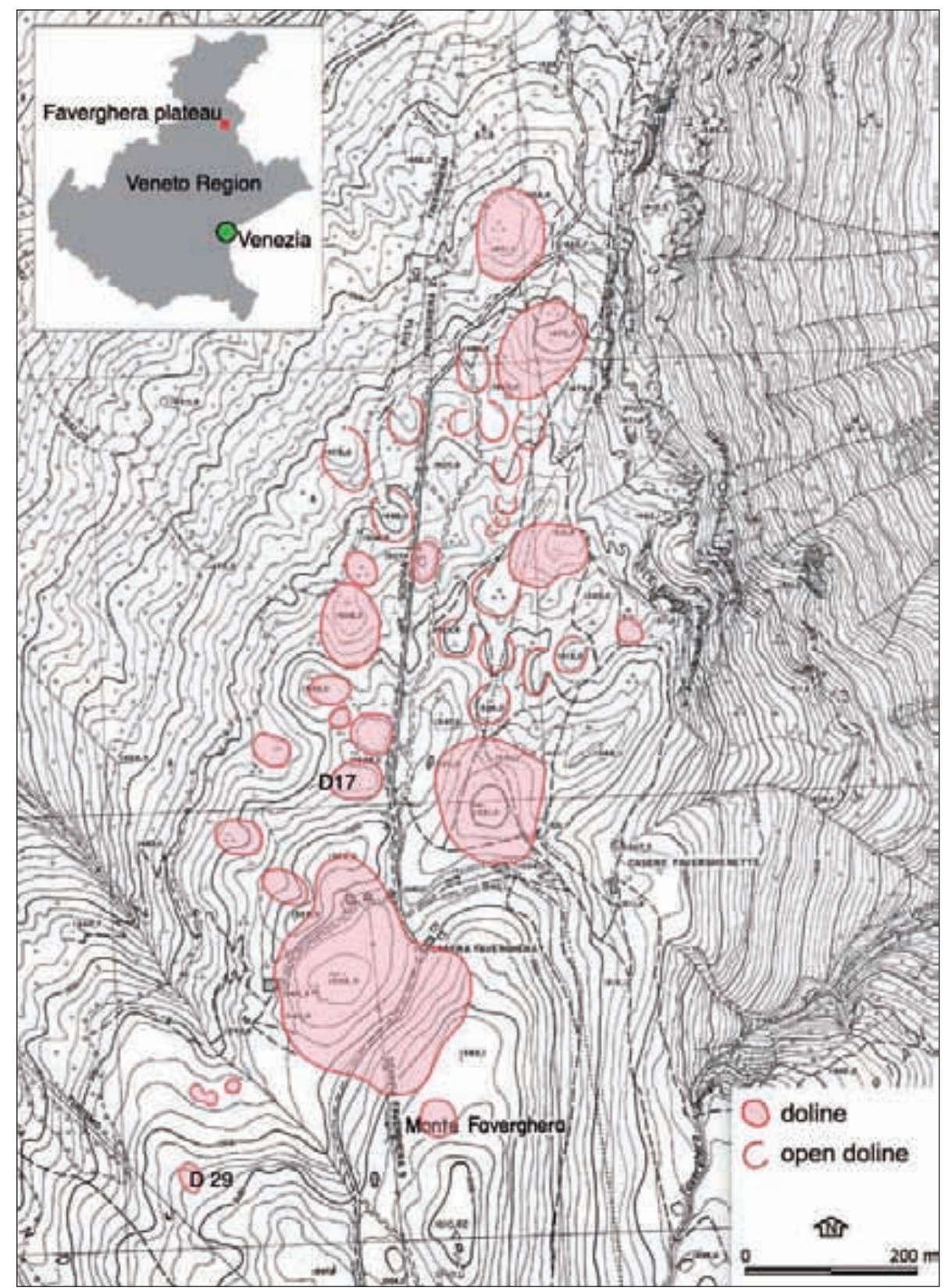

Fig. 1: Sketch of the doline population of the Faverghera plateau, based on the topographical map of the Veneto Region.

fills. After an in-depth study of the structure of a doline, an attempt may be made to outline its evolutionary history and, based on the fill material, reconstruct the sequence of paleoenvironmental events that have left their mark. At this point it is only natural to ask whether the fills can constitute important records for reconstructing a climatic-environmental evolution. Do these records have any significance or undetermined structures that merely pose new questions instead of giving answers? To face these questions, an interdisciplinary approach has been developed to study a small doline population situated on the Faverghera plateau $\left(12^{\circ} 17^{\prime} 50^{\prime \prime}\right.$ to $12^{\circ} 18^{\prime} 15^{\prime \prime}$ East, $46^{\circ} 04^{\prime} 45^{\prime \prime}$ to $46^{\circ} 05^{\prime} 18^{\prime \prime}$ North), along the northern side of Col Visentin found on the ridge of Treviso, inside the chain of the Venetian Pre-Alps (Fig. 1). On two of the 36 dolines, named D17 and D29, various investigation methods were implemented and more precisely: a topographic survey, a geophysical investigation by electric resistance tomography, a study of the soil and fill material and palynological analyses.

\section{THE DOLINES OF MONTE FAVERGHERA}

The Faverghera plateau extends from North to South for just over $1 \mathrm{~km}$ and reaches a maximum width of about $500 \mathrm{~m}$. The morphology of this area have many similarities with other Pre-Alpine areas such as, for instance, the Naole plateau in Southern Monte Baldo and the Candaglia plateau in the Cansiglio-Cavallo Group. The plateau represents the relict part of an ancient planation surface, raised and tilted towards north by the tectonic movements that affected the anticlinal ridge of the Pre-Alps of Treviso (Costa et al. 1996; Pellegrini 2000; Caneve 2000; Ferrarese \& Sauro 2006).

In an area of about $336,000 \mathrm{~m}^{2}$ at least 36 dolines have been surveyed, giving a density of little less than 107 dolines per $\mathrm{km}^{2}$. Morphometric analysis has been made according the method of Bondesan et al. (1992). These dolines cover about $34 \%$ of the area and are the results of accelerated karst solution that affects nearly half the entire area (Fig. 1). The volume of rock ero- 
sion caused by the accelerated solution counts around $1.306,000 \mathrm{~m}^{3} / \mathrm{km}^{2}$.

The flat bottom of many dolines shows that these depressions have only been partly filled by sediments, so only the top of the rock form can be seen (Fig. 2). These sediment fills show that 16 of the 36 dolines appear as open dolines, having completely filled the depression to its rim.

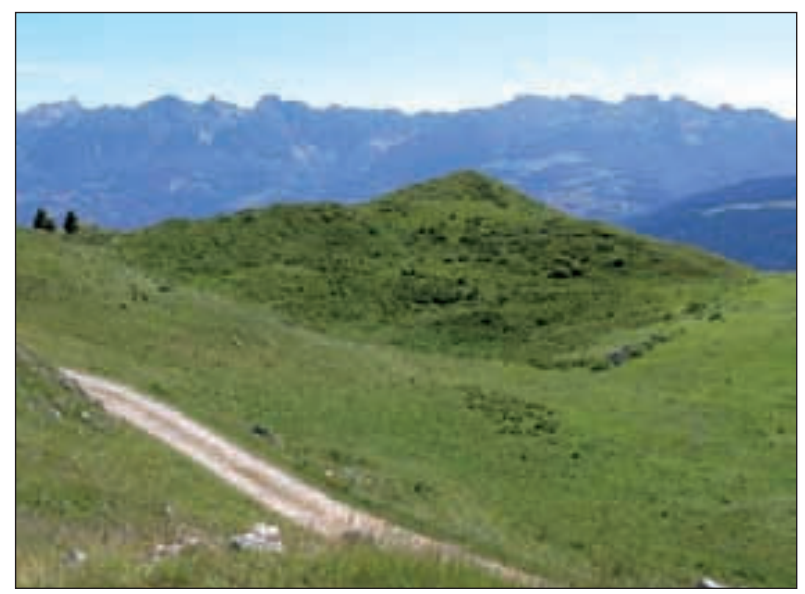

Fig. 2: A large doline of the Favergera plateau. In the past this form has been completely filled up to the rim as evidenced by the presence of terraces. Later the fillings have been partly evacuated with development of a smaller doline nested in the main form (Photo: U. Sauro).

The largest doline of the area covers nearly $40,000 \mathrm{~m}^{2}$ and has a volume of about $165,000 \mathrm{~m}^{3}$, while the smallest is a mere $116 \mathrm{~m}^{2}$ with a volume of $270 \mathrm{~m}^{3}$. The deepest doline measures a minimum depth of $10 \mathrm{~m}$ and maximum depth of $26 \mathrm{~m}$, while many small dolines, completely filled by sediment, have depths that vary from 0 to $2 \mathrm{~m}$.

To analyse in detail the topography, the two dolines D17 (Fig. 3) and D29 (Fig. 4) have been chosen: both dolines have a flat bottom that ensure presence of filling. In D17 45 points were measured, including 27 of the bottom. This covers $951 \mathrm{~m}^{2}$, equivalent to $48.5 \%$ of the planimetric surface of the doline, and has a slightly elliptic form with its widest and smallest diameters measuring $41 \mathrm{~m}$ and $29.5 \mathrm{~m}$ respectively. The 45 points were processed to create a digital elevation model.

Doline D29 is situated on a slope facing NW, and since it is elongated along the slope, it mimics a small blind valley. Its maximum and minimum depths are $18.5 \mathrm{~m}$ and $1.7 \mathrm{~m}$. It is rockier than doline D17. 48 topographic points were measured, with 29 on the bottom, which were used to create a digital elevation model. The bottom covers $358 \mathrm{~m}^{2}$ and is $34 \mathrm{~m}$ long.

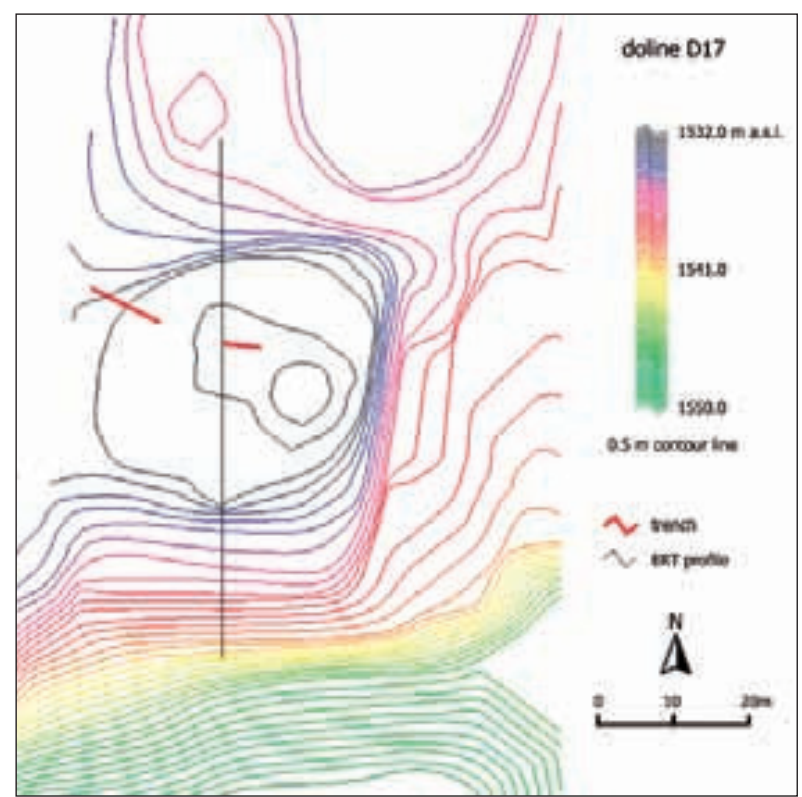

Fig. 3: Detailed topography of D17 (obtained by a field survey).

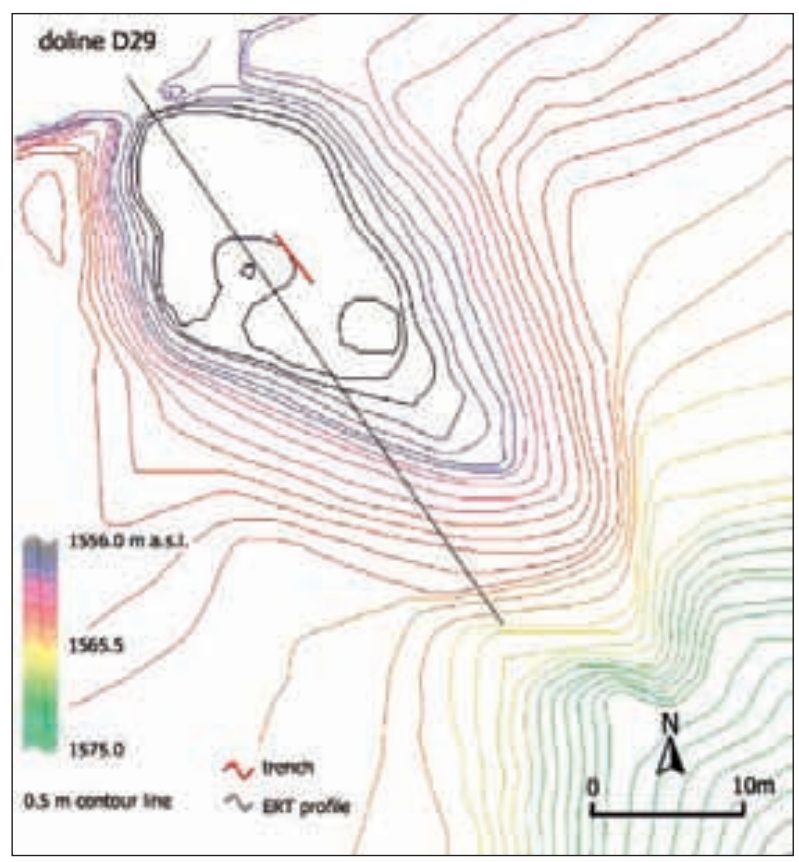

Fig. 4: Detailed topography of D29 (obtained by a field survey).

\section{GEOPHYSICAL PROSPECTIONS}

Geophysical investigations were carried out on the two dolines using Electric Resistance Tomography (ERT). The contrast of electric properties between the limestone bedrock (typically very resistive) and the doline fill material (highly conductive) make resistivity imaging the ideal technique for geometric characterisation of the doline 
and for mapping the contact between fill material and the bedrock.

A resistivity meter IRIS Syscal Pro 48 channel was used for this scope. The Syscal Pro integrates an energising unit (with a maximum voltage capacity of $800 \mathrm{~V}$ ), a commutation matrix for addressing the quadripole electrodes, ten read channels and a voltage and current metering unit.

Two ERTs profiles were collected. D17 and D29, along the median axes of the corresponding dolines. The resistivity measurements were carried out using 48 electrodes, with an interelectrode spacing of 2.0 and $1.5 \mathrm{~m}$ respectively, in Wenner configuration. This configuration was chosen after carrying out field tests to obtain a greater depth penetration capacity. The length of each profile was 94 and $70.5 \mathrm{~m}$ respectively. Each profile consisted of 360 mapping points, obtained by measuring resistivity up to ratio 16 (ratio intended as the relation between the energising dipole distance and the dipole spacing). Contact between the electrode and the ground was ensured by making a hole with a slightly larger diameter com- pared to the electrode $(12 \mathrm{~mm})$, flooded with a suitable saline solution after inserting the electrode. The use of the highly conductive solution minimised the problems of connection resistance in the areas of exposed rocks.

The configuration and geometry chosen for the mapping obtained a maximum investigation depth of approximately $15 \mathrm{~m}$ below the surface (for tomography D17).

The result of the investigation indicate a field of variation in resistivity from 40-50 ohms per metre to several thousand ohms per metre. The electric tomography profile of doline D17 clearly mapped the geometry of the doline sedimentary fill (Fig. 5). The thickness of the fill material is estimated to be $6.0-6.5 \mathrm{~m}$. In the case of D29 also the geometry of the doline fill material was clearly mapped (Fig. 6). The doline exibits a basically symmetrical shape and the geometry of the boundary between fill and bedrock reasonably well corresponds with the two side slopes. The thickness of the fill material is estimated to be $4.5-5.0 \mathrm{~m}$. Other strong resistivity anomalies were also noted that may indicate the presence of cavities and voids.

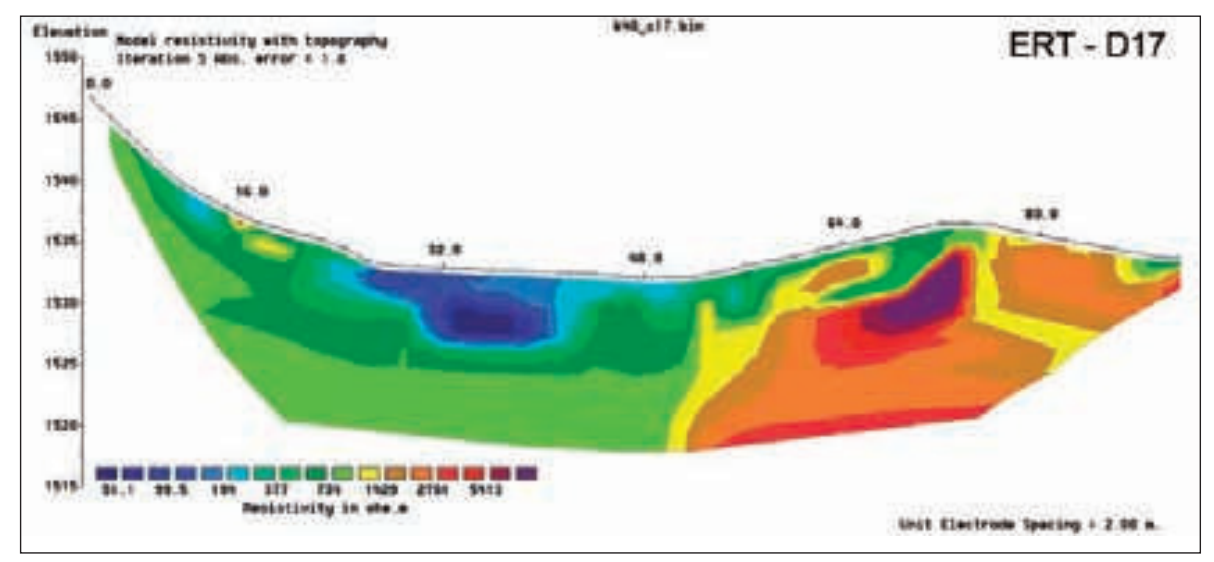

Fig. 5: Electric tomography profile of D17.

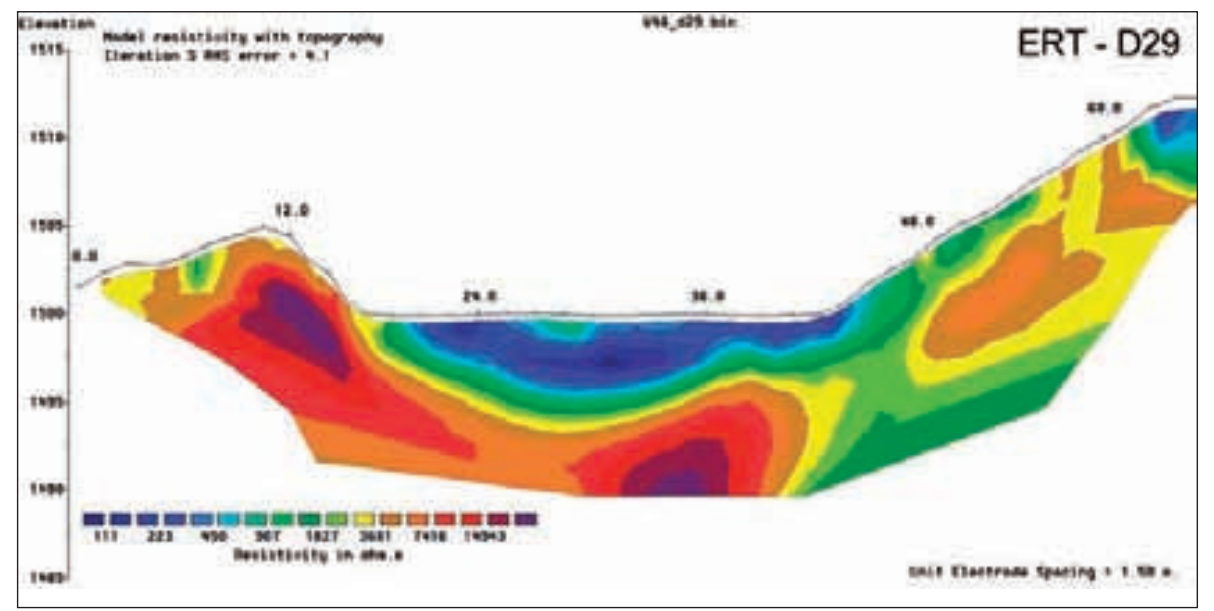

Fig. 6: Electric tomography profile of D29.

\section{THE SEDIMENTARY FILLS}

In order to determine which processes effectively contributed to fill the karst depressions of Faverghera, two trenches were excavated in dolines D17 (Fig. 7) and D29, to a maximum depth of $2 \mathrm{~m}$. Two sections were described according to the current soil description code (Sanesi 1977).

A total of 11 samples were collected from the different horizons for particle size analysis, determination of the $\mathrm{CaCO}_{3}$ content and $\mathrm{pH}$ measurement. The particle size analysis consisted in sieving the fractions between $1400 \mu \mathrm{m}$ and $63 \mu \mathrm{m}$, and analysing the sediment with particle size $<63 \mu \mathrm{m}$ by the aerometry method (Avery \& Bascomb 1974). The data has been presented using the Udden-Wenthworth scale modified according to IUSS standards 
(International Union of Soil Science), which lowers the clay limit from 4 to $2 \mu \mathrm{m}$. Particle sizes are expressed as phi $=-\log _{2}$ (particle size in $\mathrm{mm}$ ). The $\mathrm{CaCO}_{3}$ content was determined by alcohol (Dietrich-Freuhling) calcimeter. The $\mathrm{pH}$ was analysed using the Gale \& Hoare method (1991).

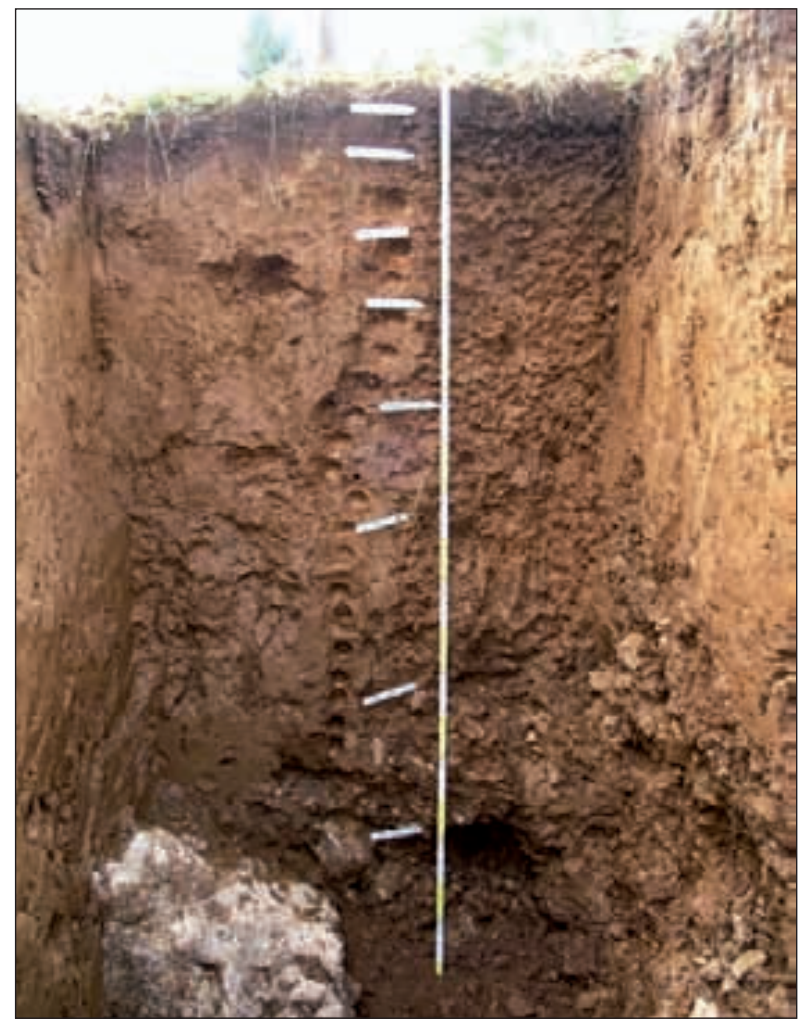

Fig. 7: The trench excavated in doline D29 showing the cavities of the sampling for the analysis.

Eight undisturbed samples were collected for thin section micromorphological analysis. The samples were impregnated with liquid synthetic resin (i.e. polystyrene) that filled the porosity of the sample. When the resin had hardened, making the soil sufficiently firm, the thin sections were cut. The thin sections are $20-30 \mu \mathrm{m}$ thick slices mounted on $120 \times 90 \mathrm{~mm}$ glass trays. The micromorphological description of the soil thin sections follows Bullock et al. (1985), terms from Brewer (1976) were also employed in order to emphasize certain concepts or better describe some features from the point of view of interpretation.

The samples of the fill in doline D17 show a very homogenous overall trend both in their cumulative particle size curves, and in the percentage content of sand, silt and clay (Fig. 8). It can be noted that the gravel fraction $(>2,000 \mu \mathrm{m})$ is totally absent in all five samples. The sand fraction $(2,000 \mu \mathrm{m}-63 \mu \mathrm{m})$ is present in all samples in very low percentages ranging from a maximum of $5.05 \%$ in the uppermost sample of the profile to a minimum of $2.15 \%$ in the lower sample. The silt fraction has significant percentage contents that range from a maximum of $68.85 \%$ in the lowest sample to a minimum of $60.95 \%$ for the uppermost sample. The clay fraction $(<2 \mu \mathrm{m})$ is also well represented with maximum percentages of $35 \%$ in sample from horizon EB (10-15 cm; 7.5 YR 4/4) and minimums of $29 \%$ in the lowest sample. The calcium carbonate content is extremely low in all samples, in fact no case was found to be above $0.3 \%$. The doline fill has $\mathrm{pH}$ values of $5.1-5.4$, which get down to 4.1 and 4.6 in the upper A and $\mathrm{EB}$ horizons respectively.

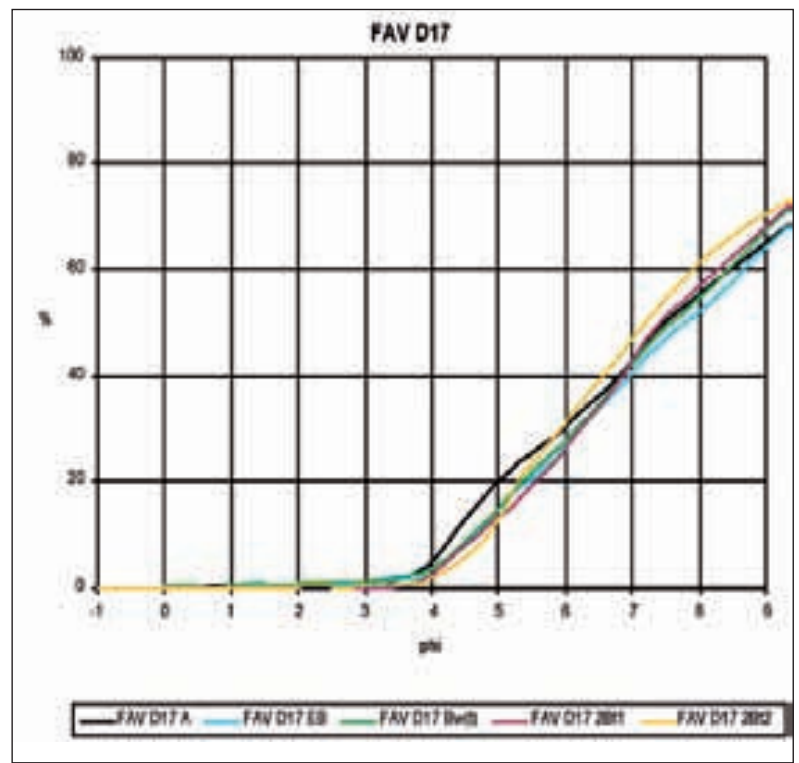

Fig. 8: Cumulative particle size curves of five samples of D17; phi $=-\log _{2}$ (particle size in $\mathrm{mm}$ ).

The data for doline D29 evidence a slight difference between the various samples (Fig. 9). Also in this doline the gravel fraction is totally absent. The sand fraction has a relatively higher percentage $(11.86 \%)$ in the uppermost sample and reaches a minimum of $1.12 \%$ in one of the lowest samples. Silt is present in maximum percentages of $82.51 \%$ in sample $\mathrm{Bw}(\mathrm{t}) 2(28-42 \mathrm{~cm})$ and reaches a minimum of $71.14 \%$ in the lowest sample. The clay goes from a maximum of $27 \%$ in the lowest sample to a minimum of $9 \%$ in the uppermost one. Again in doline D29 the calcium carbonate content is extremely low and does not exceed $0.3 \%$. As regards the $\mathrm{pH}$, the data are very similar to doline D17, with values of 4.7 and 4.5 in the upper $\mathrm{A}$ and $\mathrm{Bw}(\mathrm{t}) 1$ horizons and increasing in depth to 5.2 - 5.9.

The particle size cumulative curves of all samples of the filling of the two dolines have been compared. Two 


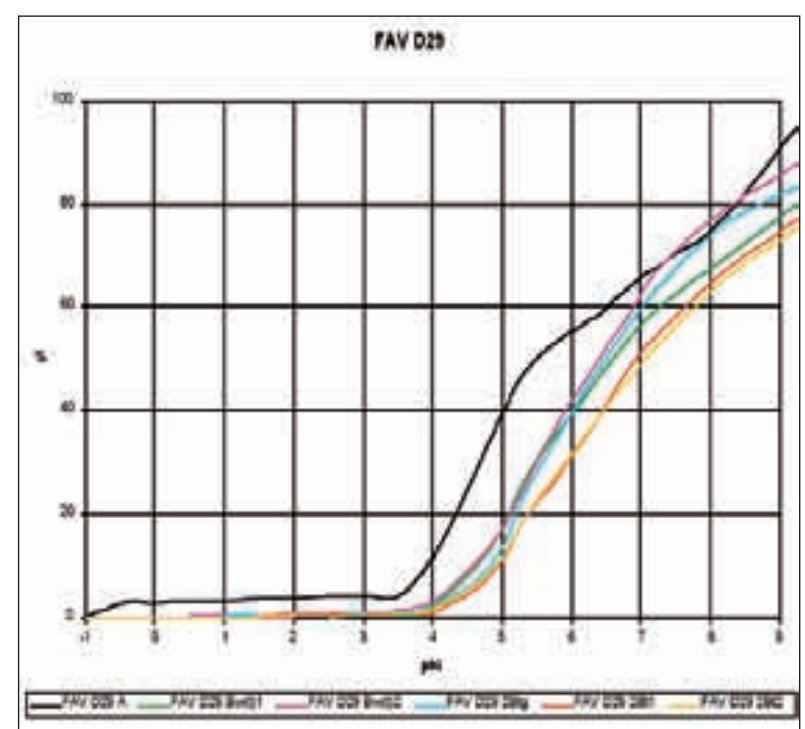

Fig. 9: Cumulative particle size curves of six samples of D29; phi $=-\log _{2}$ (particle size in $\mathrm{mm}$ ).

main categories can be recognized according to the curve trends. The first category represents the samples from doline D17, which all show similar trends with slightly lower silt contents. This category can be compared to the two lowest samples of doline D29. The second grouping includes the upper samples of doline D29, which all show higher silt percentages.

The micromorphological investigation of the fill in doline D17 highlights how all the material has undergone mechanical action that has led to an overall homogenisation of the profile (Fig. 10). However a dual origin of the

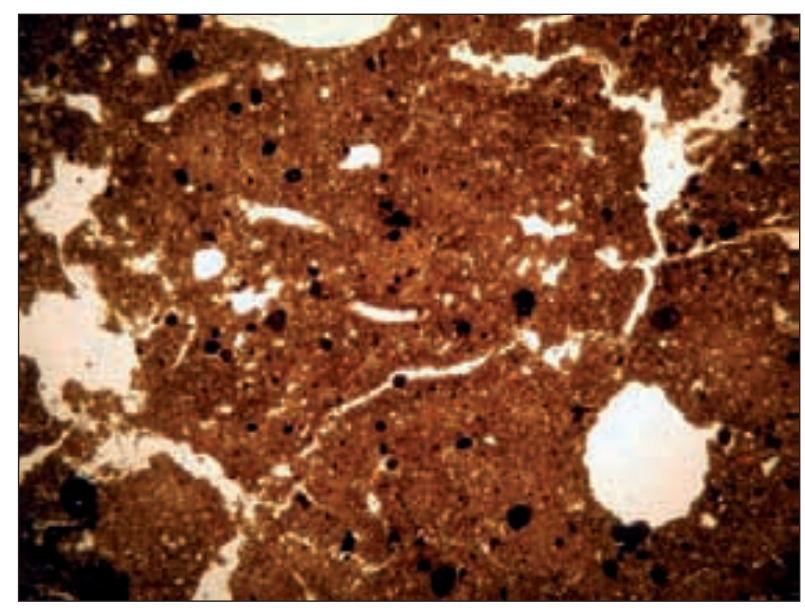

Fig. 10: Massive microstructure of horizon Bw in doline D17, with many sub-rounded channels (16x PPL).

fill material can be perceived, thanks to the identification of reddish soil fragments in the lower units. Reworking, which may have also involved a limited colluvial transport phase in the lower units (indicated by the presence of typical pedorelicts, papules and nodules) appears in a different way in the two units, since the upper unit has been more liable to bioturbation while the lower one is characterised by pedoturbation (particularly argilloturbation, Fig. 11). Nevertheless this type of mechanical reworking has not cancelled the evidence of previous pedogenetic phases, such as for instance the clay illuviation of the lower unit. Finally, the very fine particle size of all the sections has permitted iron segregation in the form of nodules, impregnations and coatings throughout the profile.

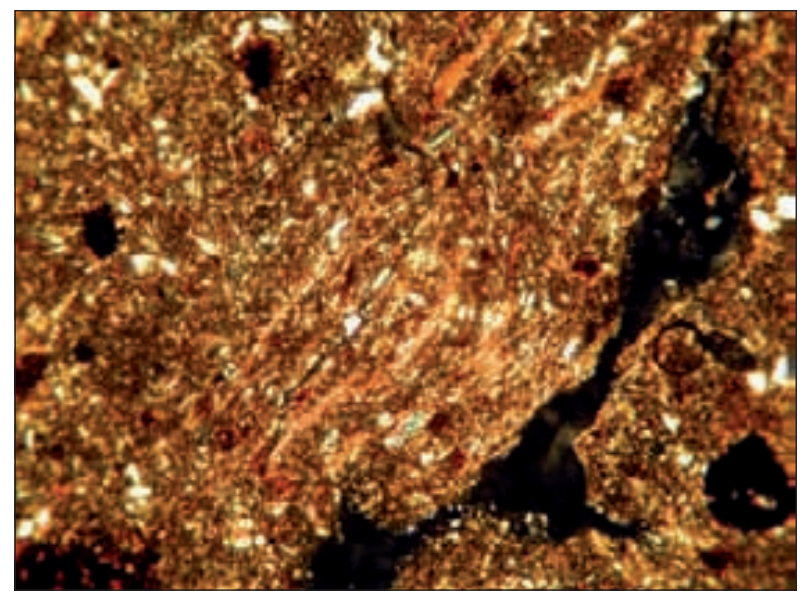

Fig. 11: Striated b-Fabric included by argilloturbation in horizon 2Bt1, doline D17 (100x PPL).

The micromorphological investigation of the fill in doline D29 highlights how the profile has originated from two distinct fill parent materials, separated by a transition horizon. The lower unit has been affected by several clay illuviation phases, evidenced by impure clay and pure clay coatings at different states of preservation (Fig. 12). It shows greater reddening in the micromass and its upper part has undergone phenomena related to the hydromorphic process (Fig. 13), which decreases with depth. The presence of some rounded, reddish pedorelicts suggests the erosion of well developed soils around the doline and colluvial deposition at the bottom of the doline fill (Fig. 14). The upper unit shows lesser degrees of pedoplasmation (with the exception of the iron segregation, which nevertheless affects the whole profile) and clay illuviation, which opposes a greater bioturbation; the groundmass is coarser and the micromass is less reddened. As regards profile reworking, this is perceivable, although limited and predominantly conditioned by the bioturbation in the upper unit (Fig. 15) and in some way tied to colluvial transport and sedimentation of the material. 


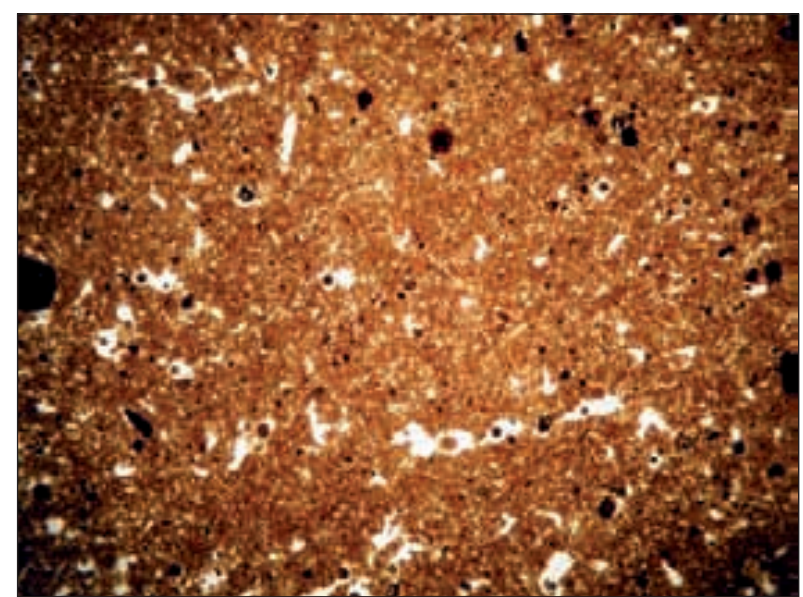

Fig. 12: Well preserved laminated clay coating partially filling a void in horizon 2Bt1, doline D29 (100x PPL).

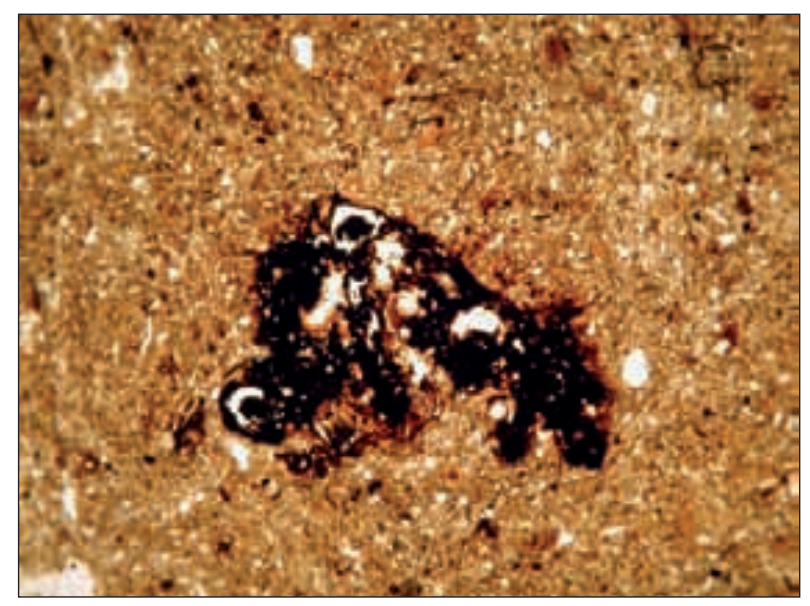

Fig. 13: Ameboidal Fe/Mn nodule in horizon Btg indicating poor soil drainage, doline D29 (40x PPL).

All the fill of doline D17 can be explained in the deeper part as the insoluble residue of weathered material and, in its upper part, as the simple colluvial builds up of pedogenised material from erosion of the soil around the doline. The overall homogeneity of the sedimentary fill of this doline would seem to exclude the presence of significant inputs of aeolian origin.

Doline D29 presents granulometric data that follow two different trends. The cumulative particle size curve shows how the trend of the three upper samples differs slightly from that of the two lower samples: the silt content of these 3 samples is higher that all the other samples. This could suggest an input of different material to that originating solely from limestone dissolution. One hypotheses is that the material originating from the colluviation inside the doline was previously enriched in loess and, once sedimented in the doline, did not constitute well defined horizons, characterised by a clear input

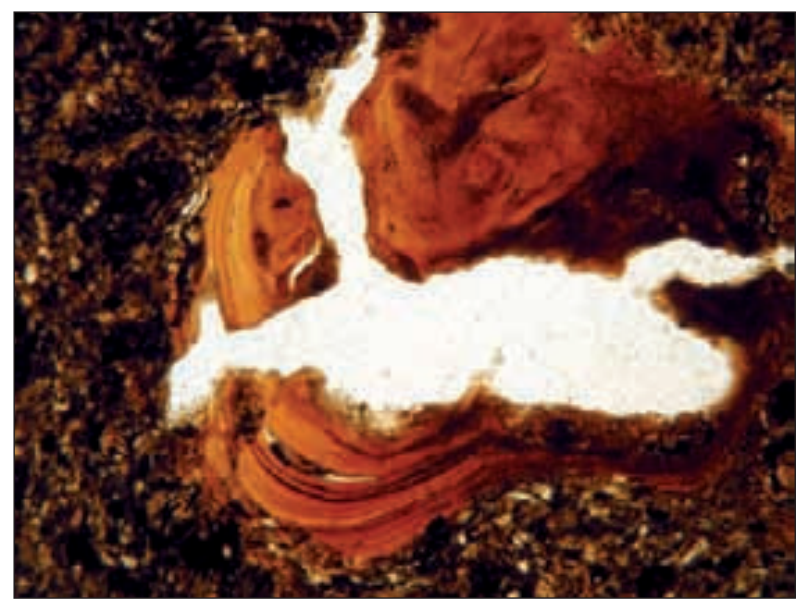

Fig. 14: Reddish pedorelict in horizon 2Bt2, doline D29 (100x $P P L)$.

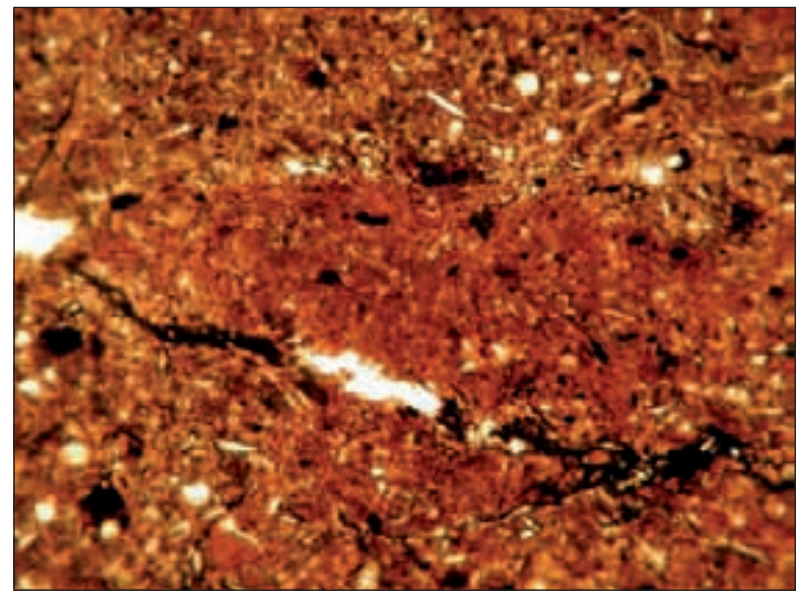

Fig. 15: Microstructure of horizon Bw1 with several channels in doline D29 (16x PPL).

of silt, but merely a general enrichment of the silt fraction in the upper part of the pedological profile. What's more, even the post-depositional bio-pedoturbation processes may have contributed towards a homogenisation of the profile. On the other hand, the uppermost sample shows a distinctive particle size trend by having a much higher sand content, probably due to allochthonous material moved by anthropic activity in the area. The lower silt content and higher clay content of the two lower samples can be explained by a pedogenetic weathering of the doline bedrock.

From these investigations, it results that the sedimentary fills of the dolines are highly pedogenised and can be considered as belonging to the so-called "Terra Rossa", very red soils that develop on limestone in the Mediterranean area (Yaalon 1997; Duchaufour 1983). According to the WRB classification Terra Rossa is recognised as Luvisols (Chromic Luvisols), Phaeozems 
(Haplic Phaeozems or Luvic Phaeozems) and Cambisols. In general terms, the typical polygenetic nature of Terra Rossa derives from an accumulation, to different extents, of the residue of the carbonate parent material dissolution (Kubiena 1970; Duchaufour 1983) together with inputs of allochthonous material (Macelod 1980) both by erosion of neighbouring slopes (Olson 1980), and by short range aeolian inputs (Galdieri 1913)l; Vanmechelen et al. 1993). In the case of Faverghera, the best developed horizons reach maximum Munsell hue of 7.5 YR. The analyses have shown how this Terra Rossa has a polygenetic origin that has been influenced by both autochthonous inputs (insoluble residue) and allochthonous inputs (colluvial/loess). Moreover it can be concluded that the two dolines have a slightly different genesis.

From the sedimentological point of view, doline D17 has a very homogenous fill, characterised by a total absence of the gravel fraction, an extremely low percentage of sand, a moderate input of silt and a high presence of clay. The abundant clay fraction represents the pedogenisation of the insoluble residue produced by the carbonatic dissolution of the bedrock, also sustained by the extremely low, if not absent, calcium carbonate content. The silt fraction derives by an input of colluvial origin of material in the area around the doline. This homogeneity is also reflected in the micromorphological characteristics, which nevertheless allow this phenomenon to be attributed to mechanical processes, both bioturbation and argilloturbation; the thin sections show the dual origin of the fill material (insoluble residue and colluvial material), a more ancient pedogenetic phases (clay illuviation) and the more recent pedogenesis (iron segregation).

As regards doline D29, the sedimentological conclusions suggest that the fill was constituted by two main sequences. The lower part of the pedological profile (below $0.6 \mathrm{~m}$ from surface) shows very similar sediment to doline D17, rich in pedogenic clay that probably derives from the original bedrock of the doline. On the contrary, in the upper layer there is greater silt content compared to doline D17. However the silt is not identified in a precise pedogenetic horizon, but is homogeneously distributed along the whole upper part of the pedological profile. This suggests the hypothesis that the input of material probably of aeolian origin (i.e., loess) had not directly involved the doline but rather the neighbouring slopes. The loess inputs must have reached the doline only later, by a short range colluvial processes. Even the micromorphological survey confirms the dual origin of parent material: the lower unit has been affected by several clay illuviation phases and shows a greater reddening, proof of ancient pedogenetic phases, while the upper unit shows a lower level of pedoplasmation and clay illuviation, and a different mineral fraction. Even in this case processes can be identified that have lead to an overall homogenisation of the profile (bioturbation and pedoturbation) and traces of a recent pedogenetic phase, characterised by iron segregation. Finally, the uppermost part of doline D29 recorded sand inputs from outside of the doline, probably the result of anthropic activity in the surrounding areas.

\section{POLLEN ANALYSIS}

With the aim of reconstructing the palaeoenvironment evolution in the period of the Doline 29's fill, pollen analysis has been carried out. Eleven samples were taken in the trench from the depth of $33 \mathrm{~cm}$ to the depth of $146 \mathrm{~cm}$ below the ground level. Eight stratigraphic units (US) were described and identified as US 1 to US 8 starting from the surface. Pollen samples were collected from the US 3 to the US 8 (Fig. 7). Subsamples of 10-20 g of fresh sediment were chemically treated to extract the palynomorphs as follows: cold and hot Na-pyrophosphate $10 \%$, filtration with $200 \mu \mathrm{m}$ sieve, cold $\mathrm{HCl} 20 \%$, cold $\mathrm{HF} 50 \%$ for 12 hours (twice), $\mathrm{HCl} 20 \%$ at $90^{\circ} \mathrm{C}$ for 1 hour, acetolysis, filtration with $10 \mu \mathrm{m}$ sieve, $\mathrm{KOH} 10 \%$. Lycopodium spores were added to obtain estimates of pollen concentration per gram of sediment. The residue was stained with basic fuchsine and mounted in glycerol. Pollen and spores were identified according to Moore et al. (1991) and Large and Braggins (1991). The algal cysts and fungal spores were identified using descriptions and photos of Ahrens (1996) and Van Geel et al. (1981). The state of preservation of pollen and spores was recorded as well preserved, deteriorated (crumpled/ broken, corroded and degraded) or obscured (with mineral particles inside) according to Delcourt and Delcourt (1980). Whole slides were counted and at least two slides for sample were analyzed. Pollen percentages of terrestrial spermatophytes (trees, shrubs and herbs) were calculated on the basis of their pollen sum (Pollen Sum) only from the US 8 counts. For the other groups (Helophytes, Aquatics, Undeterminable pollen, Pterydophytes, Algae and Fungi) the basis sum included the Pollen Sum and, in turn, each group of considered palynomorphs. The pollen diagrams were drawn using TGView 2.02 (Grimm 2004). Micro-charcoals $(50-200 \mu \mathrm{m})$ were counted during the pollen counting; the abundance of millimetric charcoals (greater than $200 \mu \mathrm{m}$ ) has been visually estimated in the residues of sieving.

The concentration of pollen in the richest samples of the sequence (US 8 and US 5) is very low $(<5,000$ grains/gram of fresh sediment) (Fig. 16). In the other US the concentration was not calculated. The concentration of spores (mainly Polypodiaceae) was high only in the 


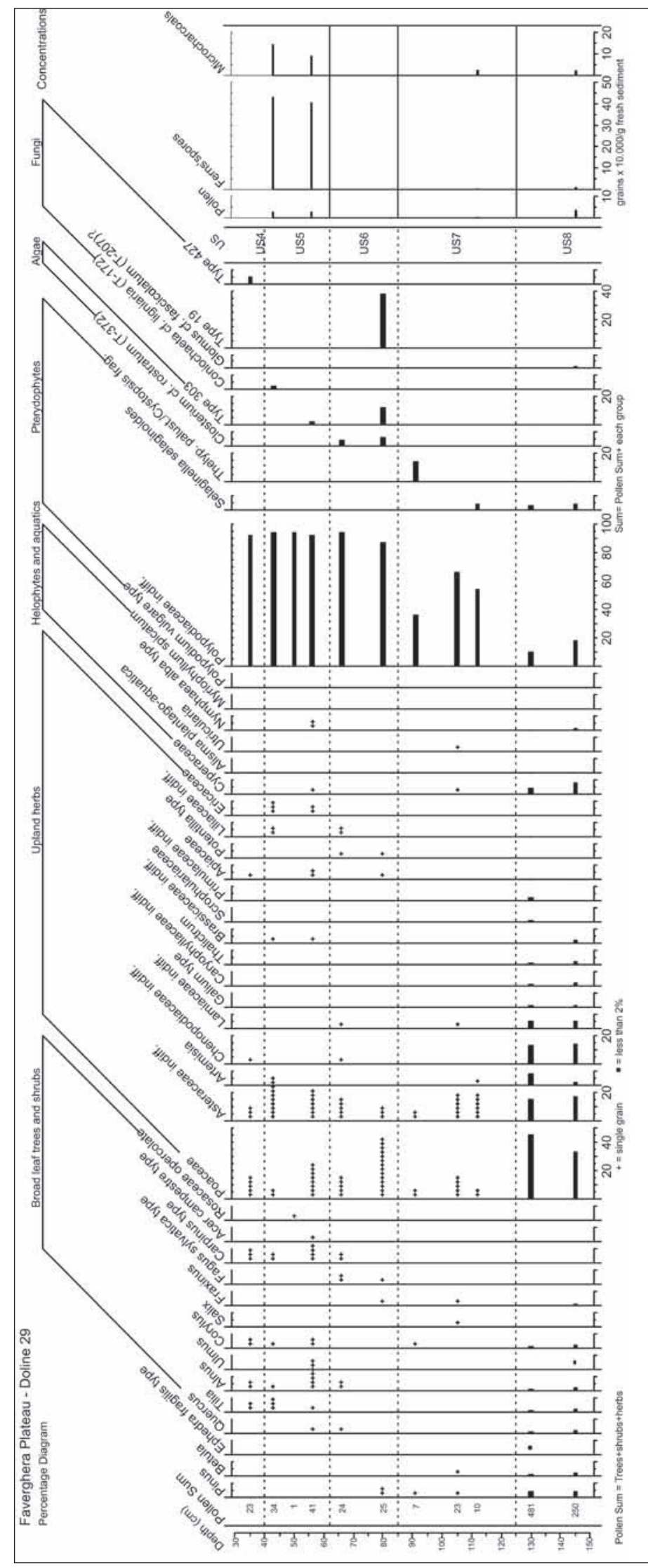

US 5. Their state of preservation is bad both in the upper US and in the lower US. This is quite indicative of unsuitable sedimentary condition in the Doline as the Polypodiaceae spores with Pinus pollen are the most resistant sporomorphs to the degradation (Birks \& Birks 1980).

A very bad preservation characterized all the grains of the two lower US 8 and 7 (deteriorated grains more than $90 \%$ ) (Fig. 17, A). In US 6 and 5 a low percentage (13-26\%) of well preserved grains was detected. Among the deteriorated grains (Fig. 17, B), the dominance of broken, crumpled and degraded grains suggests that the grains have undergone chemical oxidation within aerial and subaerial environments and physical transport with fine sediments. Differently the percentage of corroded grains is low (5 \% $-15 \%$ in the US 5 and 6 ). According to Delcourt and Delcourt (1980) the corrosion is the effect of the biological oxidation. The low $\mathrm{pH}$ measured in the sediments of Doline 29 may have limited the bacterial decomposers and therefore the corrosion of the grains. However the high level of pedogenesis observed in the sediments can explain the very poor state of preservation of the grains and the low concentration of grains as well. This sedimentary condition limits the potentiality of pollen analysis in the reconstruction of the palaeoenvironmental history of the area. However some interesting findings can suggest working hypotheses that could be verified in sediments more suitable for pollen analysis (sediments of damp areas still existing in the Faverghera Plateau).

1. At the bottom of the sequence the pollen association is characterized by light-demanding and pioneer herbaceous taxa as Poaceae, Asteraceae, Artemisia, Chenopodiaceae, Galium and Selaginella selaginoides. The arboreal/arbustive component is very low and it is represented by Pinus, Betula and Ephedra. The chlamydospores of Glomus cf. fascicolatum suggest the presence of this mycorrhizic fungus that is hosted by various plants, including birch, which could therefore be a local component of the flora, probably as Betula nana. The vegetation is typical of cold and steppic environments. Rare findings of pollen produced by thermophilous plants as oak

Fig. 16: Pollen percentage and concentration diagram of Doline 29 in Faverghera Plateau. 


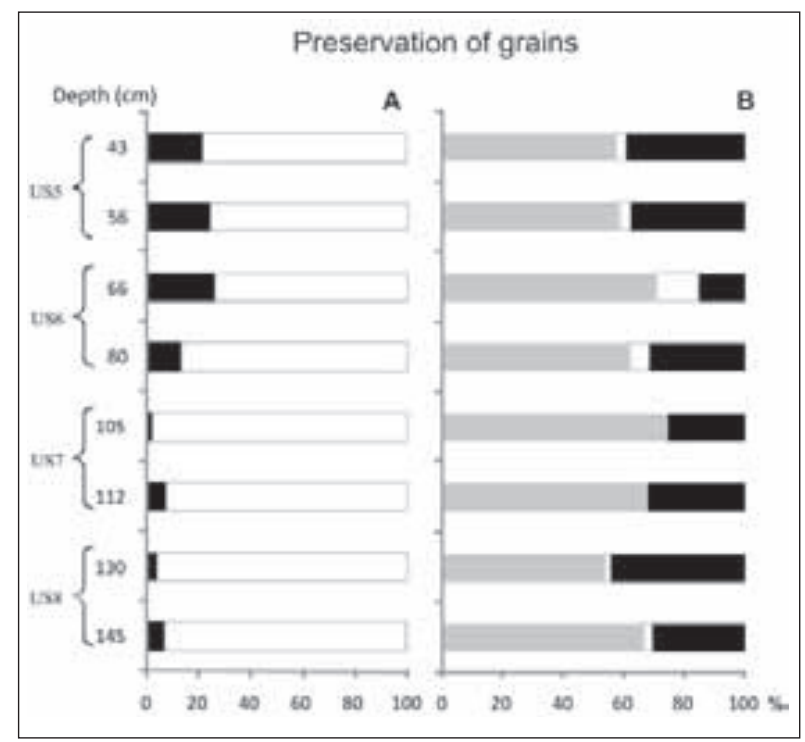

Fig. 17: Preservation of pollen and spores in the sediments of Doline 29. A. Well preserved grains (black) and deteriorated grains (white). B. Distribution of deteriorated grains in the classes of crumpled/broken grains (grey), corroded grains (white) and degraded grains (black).

(Quercus), lime (Tilia), hazelnut (Corylus), elm (Ulmus) and ash (Fraxinus) are not in accordance with this palaeoenvironmental reconstruction. The following hypotheses can be proposed about pollen origin:

A. Extra-local origin from contemporary vegetation growing on the southern face and/or at lower altitudes; this hypothesis is in contrast with the general belief that soil provides strictly local information, but the particular exposure of the Faverghera area, with its opening towards the plain, could be an exception. In this case the deposition of the sediments of US 8 could start after the appearance of the broad leaf trees in the prealpine area, that has been dated after 15000-12500 yrs BP (Casadoro et al. 1976; Albanese 2003; Vescovi et al. 2007).

B. Re-deposition of superficial sediments originated during temperate periods in strong winds and open landscape conditions. In this case the pollen association suggests that the US 8 could deposited during the last glacial maximum.

2. In the US 6, 5 and 4 the number of broadleaf trees' pollen taxa increases with beech (Fagus sylvatica), hornbeam (Carpinus betulus) and maple (Acer), while Pinus disappears. Lime and beech are poor producers of pollen, therefore pollen in the sediment could be indicative of the presence of the plants. It is worth noting that today they do not normally reach the altitude of $1,500 \mathrm{~m}$ a.s.l. (Pignatti 1982). As far as the local flora concerns, the absence of Pinus in the pollen spectrum is particularly significant because, after the Polypodiaceae spores, Pinus pollen presents the best conservation in sediments and the plants are the greatest producers of pollen. Unfortunately the scarcity of pollen in these units does not allow any hypothesis on the age of the sediment or the evolution of the forestation (beech ?) in the area. However with due caution, given the quality of the material analysed, it seems feasible to suggest that the upper $70 \mathrm{~cm}$ sediments filled in the doline when a warm and humid climate was already established, to permit the expansion of the broadleaf forest near the study site, probably at the onset of Holocene (Vescovi et al. 2007).

3. Indicators of the presence of human activities in the area were found in the US 5. Spores of fungi that grow on dung and wood (Coniochaeta cf. lignaria), microcharcoals (Fig. 16) and millimetric carbons (Fig. 18) could be indicative of the presence of cattle and local fires.

\begin{tabular}{|c|c|c|}
\hline US & Depth $\quad(\mathrm{cm})$ & Visual estimation \\
\hline US4 & $35-38$ & Abundant $1-2 \mathrm{~mm}$ \\
\hline US5 & $43-46$ & Common $1-2 \mathrm{~mm}$ \\
\hline US5 & $50-53$ & - \\
\hline US5 & $56-59$ & - \\
\hline US6 & $66-69$ & Common $<1 \mathrm{~mm}$ \\
\hline US6 & $80-83$ & - \\
\hline US7 & $91-94$ & - \\
\hline US7 & $105-108$ & - \\
\hline US7 & $112-115$ & - \\
\hline US8 & $130-133$ & - \\
\hline US8 & $145-148$ & $\begin{array}{l}\text { Common }<1 \mathrm{~mm} \\
\text { Very Abundant Glomus }\end{array}$ \\
\hline
\end{tabular}

Fig. 18: Tab. evidencing the abundance of millimetric charcoals.

The sediments of the Doline 29 did not preserved the pollen rain of the surrounding vegetation in order to reconstruct the vegetation history and the past land use. Nevertheless the rare findings can suggest hypotheses about the origin of the sediments that filled in the doline for future investigations. 


\section{DISCUSSION}

The results of the investigation highlight the complexity of karst dolines and their history (Gams 2000; Sauro 2004). Each doline has its own characteristics that differ to the adjacent dolines, even though similarities have been found for a given population which expresses the typicality of that family of forms. Beside this, even if some significant data emerge form the study of the fillings, it is difficult to reconstruct the environmental history of the area.

From the geomorphological point of view, investigations on other populations, topographically similar to Faverghera, have shown significant differences. For instance, dolines of the Naole Plateau in Southern Monte Baldo hold fillings with much greater thicknesses, at times over $10 \mathrm{~m}$ (Fig. 19), and beneath soil and parent materials constituted by loess-like sediments, host large quantities of rocky fragments originating from a partial dismantlement in periglacial environment of the "exposed" part of the form (Magaldi \& Sauro 1982). These fragments gradually densify in depth, probably because of a "washout" of the loess like silts that originally encapsulated the actual fragments.

Therefore, an important factor in the evolution of the dolines of medium latitudes is the sensitivity to freezing of the soluble rock (i.e. gelivity) constituting them. With a high sensitivity, in the cold-humid phases, the forms are liable to a rapid dismantlement, which can cause their extinction; if very low, the forms will continue to deepen, easily overcoming the crises caused by the phases of cold climate. Another important factor, tied to the previous one, is the evacuation capacity of the swallowing systems. With high capacities, the filling materials are rapidly washed away through the subterranean karst network, particularly the fine sized grains; with low capacities the filling material will remain entrapped in the form for longer.

A fundamental question can be made, as a first result of these analyses. It is whether the filling materials of the dolines constitute significant records for a paleoenvironmental reconstruction. It is evident that the dolines are not real traps, since the material transiting through them is more than what they contain. They would be better described as "filters" that allow certain kinds of material transit more easily than others: ions in the aqueous solutions, silt drawn away by water, clay liquefied in wa- ter. The fillings also undergo many kinds of disturbances: processes tied to water percolation, processes tied to the freezing and melting of water, biological activity (various kinds of bioturbation), processes tied to intense seismic events. The filtration and evacuation speeds fall within a very wide range of variables: extreme cases observed in the Pre-Alps can be: 1) a small doline, which has never evolved as a surface form (i.e. cryptodoline), which has trapped in a filling little more than a 1 meter thick, with a soil sequence that seems to cover a history some hundred thousand years long or so; 2) large dolines of the Noale Plateau, which, after the last Pleistocene cold crisis that determined a fill up to the rim, have been evacuated up to several thousand $\mathrm{m}^{3}$ of material during the Holocene.

Therefore, it can be said that in general dolines are neither good traps, nor are they good records capable of

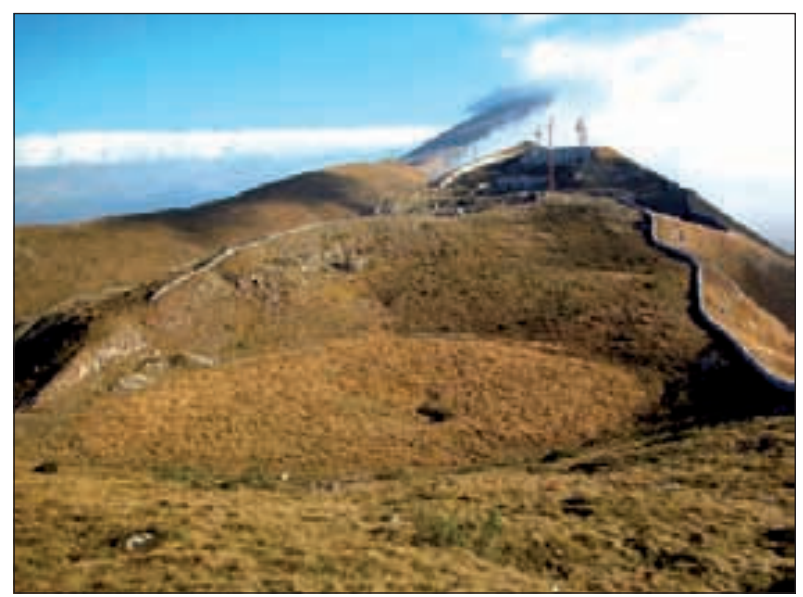

Fig. 19: A large doline of Plateau of Naole in Southern Monte Baldo. In the past this form has been filled up to the rim as evidenced by the presence of terraces. Later the fillings, more than $10 \mathrm{~m}$ thick have been partly evacuated, probably by a kind of suffosion of the silt fraction, with lovering of the nearly flat bottom (Photo: U. Sauro).

preserving inside the fillings the records of the climaticenvironmental history of the area. Nevertheless, they are records capable of providing important indications, in particular if correlated with those obtained from the studies of the speleothemes sampled in the caves of the same karst area. 


\section{ACKNOWLEDGEMENTS}

This research has been done with the support the Staff of the Giardino Botanico delle Alpi Orientali di Monte Faverghera (and in particular of Dott. Juri Nascimbeni) and of the Corpo Forestale dello Stato. We are grateful for such support. We are also grateful to the reviewers for their useful and constructive suggestions to improve the paper.

\section{REFERENCES}

Ahrens, S.J., 1996: Een palaeoecologische studie van de overgang van de Jonge Dryas naar het Holoceen in een beekvulling bij Borne (Twente).- Interne rapporten van het Hugo de Vries Laboratorium, Universiteit Amsterdam, 304.

Albanese, D., 2003: Le torbiere del Vallone Bellunese, analisi geomorfologica e palinologica.- Università di Padova, (in Italian).

Avery, B.W. \& C. L. Bascomb, 1974: Soil Survey laboratori Methods.- Soil Survey Technical Monograph, 6, Harpenden.

Birks, H.J.B. \& H.H., Birks, 1980: Quaternary Palaeoecology. Edward Arnold, London.

Bondesan, A., Meneghel, M. \& U. Sauro, 1992: Morphometric Analysis of Dolines.- International Journal of Speleology, 21 1-4, 1-55.

Brewer, R., 1976: Fabric mineral Analysis of Soils.-Robert E. Krieger Publishing Company, Hunnington, New York.

Bullock, P., Fedoroff, N., Jongerius, A., Stoops, G., Tursina, T. \& U. Babel, 1985: Handbook for Soil Thin Section Description. - Waine Research Publications, p. 152, Wolverhampton, U.K.

Caneve, F., 2000: Studio morfometrico e ambientale delle doline del Monte Faverghera.- Unpubl. PhD Thesis, Università degli Studi di Padova.

Casadoro, G., Castiglioni, G.B., Corona, E., Massari, F., Moretto, M.G., Paganelli, A., Terenziani, F. \& V. Toniello, 1976: Un deposito tardowürmiano con tronchi subfossili alle fornaci di Revine (Treviso).Boll. Comit. Glac. It., 24, 22-63.

Costa, V., Doglioni, C., Grandesso, P., Masetti, D., Pellegrini, G.B. \& E. Tracanella, 1996: Note Illustrative del $\mathrm{F}^{\circ} 063$ Belluno.- Carta Geologica d'Italia alla scala 1:50.000. Servizio Geologico d'Italia, Roma.

Delcourt, P.A. \& H.R. Delcourt, 1980: Pollen preservation and Quaternary environmental history in the southeastern United States.- Palynology, 4, 215231.
Duchaufour, P.H., 1983: Pédologie 1: Pédogenèse et Classification. Masson, Paris.

Ferrarese, F. \& U., Sauro, 2006: L'altopiano carsico di Faverghera.- Guida al Giardino Botanico della Alpi Orientali e alla Riserva Integrale di Monte Faverghera. Ufficio Territoriale per la Biodiversità di Belluno, Corpo Forestale dello Stato, Ministero delle Politiche Agricole Alimentari e Forestali, 45-61.

Galdieri, A., 1913: Lorigine della Terra Rossa (abstract).Bollettino della Società di Naturalisti in Napoli, III, XXVI.

Gale, S.J. \& P.G. Hoare, 1991: Quaternary Sediments. Belhaven Press, London.

Gams, I., 2000: Doline morphogenetical processes from global and local viewpoints.- Acta Carsologica, 29, 2, 123-138, Ljubljana.

Grimm, E.C., 2004: TGView 2.0.2. Springfield, Illinois State Museum, Research and Collections Centre.

Kubiena, W.L., 1970: Micromorphological Features of Soil Geography. Rotgers University Press, New Brunswick.

Large, M.F. \& J.E. Braggins, 1991: Spores atlas of New Zealand ferns \& fern allies.- A supplement of New Zealand Journal of Botany, 1-168.

Macleod, D.A., 1980: The Origin of the Red Mediterranean Soils in Epirus, Greece.- Journal of Soil Science, 31,125 - 136.

Magaldi, D. \& U. Sauro, 1982: Landforms and soil evolution in some karstic areas of the Lessini Mountains and Monte Baldo (Verona, Northern Italy).- Geografia Fisica e Dinamica Quaternaria, 5, 82-101.

Moore, P.D., Webb, J.A. \& M.E. Collinson, 1991: Pollen analysis. II ed. Blackwell Science Ltd.

Olson, C.G., 1980: The Terra Rossa Limestone Contact Phenomena in Karst, Southern Indiana.- Soil Science Society American Journal, 44, 1075 - 1079.

Pellegrini, G. B. (Ed.), 2000: Note Illustrative della Carta Geomorfologica d'Italia alla scala 1:50.000: $\mathrm{F}^{\circ} 063$ Belluno.- Regione del Veneto, Servizio Geologico d'Italia, Roma. 
Pignatti, S., 1982: Flora d'Italia.- Edagricole. Bologna.

Sanesi, G. (Ed.), 1977: Guida alla descrizione del suolo.C.N.R., Firenze.

Sauro, U., 2003: The dolina: emblematic and problematic karst landform.- Dela 20, 43-60, Ljubljana.

Sauro, U., 2004: Closed Depressions.- In: Culver, D. \& W., White (Eds.), Encyclopedia of Caves, Academic Press, 108-122.

Van Geel, B., Bohncke, S.J.P. \& H. Dee, 1981: A palaeoecological study of an upper Late Glacial and Holocene sequence from "De Borchert", the Netherlands.- Review of Palaeobotany and Palynology, 31, 367-448.

Vanmechelen, Luc., Van Ranst, E., Baert, G. \& A. Aru, 1993: Eolian influence in Terra Rossa soils overlying dolomite in SW-Sardinia, Italy.- Quaderni di Scienza del Suolo, 5, 59-73.
Vescovi, E., Ravazzi, C., Arpenti, E., Fisinger, W., Pini, R., Valsecchi, V., Wick, L., Ammann, B. \& W. Tinner, 2007: Interactions between climate and vegetation during the Lateglacial period as recorded by lake and mire sediment archives in Northern Italy and Southern Switzerland.- Quaternary Science Reviews, 26, 1650-1669.

Yaalon, D.H., 1997: Soils in the Mediterranean Region: What Makes them different.- Catena, 28. 
